\author{
Anna Kempa-Dymińska \\ Uniwersytet Łódzki \\ Pawet Kempa-Dymiński \\ Uniwersytet Łódzki
}

\title{
WSPÓLNY ZNAK TOWAROWY GWARANCYJNY - NARZĘDZIE PROMOCJI ZRÓWNOWAŻONEGO ROZWOJU?
}

\section{Wprowadzenie}

Wykorzystywanie w działaniach administracji publicznej na rzecz zrównoważonego rozwoju instytucji przewidzianych przez prawo ochrony środowiska czy prawo administracyjne nie nasuwa wątpliwości, wszak takie jest ratio legis tych regulacji. Zastanawiać się jednak można, czy także w innych dziedzinach prawa istnieją narzędzia, które mogłyby służyć promocji idei zrównoważonego rozwoju. Niniejszy artukuł będzie stanowił próbę odpowiedzi na pytanie, czy możliwe jest wykorzystanie w działaniach administracji publicznej na rzecz zrównoważonego rozwoju instytucji wspólnego znaku towarowego gwarancyjnego, pochodzącej z prawa własności przemysłowej.

W pierwszej kolejności, przybliżone zostanie pojęcie zrównoważonego rozwoju. Następnie zostaną zarysowane ramy prawne instytucji wspólnego znaku towarowego gwarancyjnego. Rozważania zakończy zaś próba odpowiedzi na postawione w temacie pytanie.

Wpływ na ukształtowanie pojęcia zrównoważonego rozwoju (ang. sustainable development) wywarło wiele aktów prawnych rangi międzynarodowej. W pierwszej kolejności należałoby wymienić raport „Nasza wspólna przyszłość”, który został ogłoszony przez Światową Komisję ds. Środowiska i Rozwoju. ${ }^{1} \mathrm{~W}$ dokumencie

Światowa Komisja ds. Środowiska i Rozwoju (Word Comission on Environment and Development - WCED) została utworzona w 1983 r. przez Zgromadzenie Ogólne ONZ. Komisja ta zwana jest inaczej Komisją Brundtland, jako że na jej czele stanęła premier Norwegii Gro Harlem Brundtland. Por. Z. Bukowski, Zrównoważony rozwój w systemie prawa, Torun 2009 , s. 77. 
tym określono zrównoważony rozwój jako „rozwój, który zaspokaja potrzeby obecnych pokoleń, bez narażania przyszłych pokoleń na niemożność zaspokojenia ich potrzeb". ${ }^{2} \mathrm{~W}$ raporcie wymieniono również elementy składowe omawianego pojęcia, którymi są: międzypokoleniowa oraz wewnątrzpokoleniowa sprawiedliwość, zrównoważone i umiarkowane wykorzystanie zasobów oraz zintegrowanie ochrony środowiska i rozwoju. ${ }^{3}$

Koncepcja zrównoważonego rozwoju była również przedmiotem obrad Konferencji Narodów Zjednoczonych „Środowisko i rozwój”. ${ }^{4}$ Przyjęto wówczas Deklarację z Rio w sprawie środowiska i rozwoju, ${ }^{5}$ która stanowi zbiór 27 zasad w zakresie ochrony środowiska oraz zrównoważonego rozwoju. Pojęcie zrównoważonego rozwoju znalazło odzwierciedlenie m.in. w zasadzie $\mathrm{nr} \mathrm{3,} \mathrm{zgodnie} \mathrm{z} \mathrm{którą} \mathrm{prawo} \mathrm{do}$ rozwoju musi być wypełnione tak, ażeby sprawiedliwie połączyć rozwojowe i środowiskowe potrzeby obecnych i przyszłych generacji. Zgodnie zaś z zasadą $\mathrm{nr} 4$, aby osiągnąć zrównoważony rozwój, ochrona środowiska powinna stanowić nierozłączną część procesu rozwoju i nie może być rozpatrywana oddzielnie od niego. Warto również wspomnieć o zasadzie $\mathrm{nr} 5$, traktującej o wykorzenianiu ubóstwa.

W literaturze przedmiotu zwraca się uwagę, iż przełomowe znaczenie dla ukształtowania zasady zrównoważonego rozwoju miała Konwencja o różnorodności biologicznej, ${ }^{6}$ której celem, zgodnie z art. 1, jest ochrona różnorodności biologicznej, zrównoważone użytkowanie jej elementów oraz uczciwy i sprawiedliwy podział korzyści wynikających z wykorzystywania zasobów genetycznych. ${ }^{7}$ Znaczenie tego dokumentu dla zrównoważonego rozwoju przejawia się w dostrzeżeniu, że zagwarantowanie różnorodności biologicznej pozwoli na zachowanie zasobów żywych dla przyszłych pokoleń. ${ }^{8}$

Starając się zdefiniować pojęcie zrównoważonego rozwoju wypada również odnieść się do, przynajmniej wybranych, definicji sformułowanych w doktrynie. I tak, według J. Sommera „zasada zrównoważonego rozwoju postuluje określone ułożenie stosunków między rozwojem ekonomicznym i społecznym oraz ochroną środowiska" ${ }^{9}$ Definicja ta nawiązuje do Deklaracji Politycznej przyjętej w dniu 4 września 2002 r. podczas Światowego Szczytu nt. Zrównoważonego Rozwoju w Johannesburgu. W pkt 5 tego dokumentu wskazano, iż zrównoważony rozwój składa się $\mathrm{z}$ trzech filarów: rozwoju gospodarczego, rozwoju społecznego oraz ochrony śro-

2 Our Common Future, The Word Commission on Environment and Development, New York 1987, s. 6.

3 Por. P. Korzeniowski, Zasady prawne ochrony środowiska, Łódź 2010, s. 285.

4 Konferencja Narodów Zjednoczonych „Środowisko i rozwój” odbyła się w Rio de Janeiro w dniach 3-14 czerwca $1992 \mathrm{r}$.

5 Deklaracja z Rio w sprawie środowiska i rozwoju, [dostęp: 6 kwietnia 2013], <http://www.ko.poznan.pl/pub/ftp/ Edukacja_zrownowazonego_rozwoju/DEKLARACJA_Z_RIO_1992.pdf>

$6 \quad$ Konwencja o różnorodności biologicznej sporządzona w Rio de Janeiro dnia 5 czerwca 1992 r. (Dz.U. z 2002 r. Nr 184, poz. 1532).

7 Por. P. Korzeniowski, Zasady..., op. cit., s. 288.

$8 \quad$ Ibidem, s. 288.

9 J. Sommer, Prawo a koncepcja zrównoważonego rozwoju, [w:] A. Papuziński (red.), Zrównoważony rozwój. Od utopii do praw człowieka, Bydgoszcz 2005, s. 80, [za:] P. Korzeniowski, Zasady..., op. cit., s. 296. 
dowiska. ${ }^{10} \mathrm{~W}$ literaturze podkreśla się także, iż pojęcie zrównoważonego rozwoju świadczy o dostrzeżeniu istniejących powiązań pomiędzy przyrodą a rozwojem gospodarczym, społecznym, kulturowym i cywilizacyjnym. ${ }^{11}$ D.W. Pearce i R.K. Tuner przyjmują z kolei, iż zrównoważony rozwój polega na „maksymalizacji korzyści netto $\mathrm{z}$ rozwoju ekonomicznego, chroniąc jednocześnie oraz zapewniając odtwarzanie się użyteczności i jakości zasobów naturalnych w okresie długim". ${ }^{12}$ P. Korzeniowski zauważa natomiast, iż trwałe gospodarowanie zasobami środowiska polega na zastosowaniu metod postępowania, dzięki którym możliwe jest zachowanie zasobów na stałym poziomie. ${ }^{13}$

Rozważania na temat wspólnego znaku towarowego gwarancyjnego winny być poprzedzone kilkoma uwagami natury ogólnej, dotyczącymi znaku towarowego jako takiego. W dużym uproszczeniu znakiem towarowym jest każde oznaczenie nadające się do odróżniania towarów lub usług jednego przedsiębiorstwa od towarów i usług innych przedsiębiorstw. ${ }^{14}$ Podstawową funkcją takiego znaku jest oznaczenie pochodzenia, akcesoryjny zaś charakter mają pozostałe funkcje - gwarancyjna i reklamowa. ${ }^{15}$

Znak towarowy, jako jedno z enumeratywnie wyliczonych dóbr własności przemysłowej, został uregulowany w ustawie Prawo własności przemysłowej. ${ }^{16} \mathrm{Jak}$ wszystkie pozostałe dobra szeroko rozumianej własności intelektualnej jest on dobrem niematerialnym. Wspólny znak towarowy gwarancyjny jest samodzielną kategorią normatywną znaków towarowych, ${ }^{17}$ która pojawiła się po raz pierwszy $\mathrm{w}$ polskim ustawodawstwie wraz $\mathrm{z}$ wejściem $\mathrm{w}$ życie przepisów przywoływanej już PWPU. ${ }^{18}$ Instytucja ta została uregulowana w sposób nader skromny, albowiem poświęcono jej tylko jeden artykuł - art. 137. W zakresie w nim nieuregulowanym ustawodawca odesłał natomiast do ogólnych przepisów dotyczących znaków towarowych, które winny być stosowane odpowiednio.

Zgodnie z art. 137 ust. 1 PWPU znak towarowy gwarancyjny to „znak przeznaczony do używania przez przedsiębiorców stosujących się do zasad ustalonych w regulaminie znaku przyjętym przez uprawnioną organizację i podlegających w tym zakresie jej kontroli”, zaś prawo ochronne na tego typu oznaczenie może zostać

\footnotetext{
10 Political Declaration, [w:] Report of the Word Summit on Sustainable Development. Johannesburg, South Africa, 26 Augus - 4 September 2002, Doc. A/ CONF. 199/20, United Nations, New York 2002. Ibidem, s. 285.

12 D.W. Pearce, R.K. Tuner, Economics of Natural Resources and the Environmemt, New York 1990, [za:] Z. Bukowski, Zrównoważony rozwój..., op. cit., s. 29.

13 Por. P. Korzeniowski, Zasady..., op. cit., s. 294

14 Por. M. Andrzejewski, [w:] P. Kostański (red.) Prawo własności przemysłowej. Komentarz, Warszawa 2010, s. 634-643.

15 Ibidem, s. 642-643.

16 Ustawa z dnia 30 czerwca 2000 r. - Prawo własności przemysłowej (Dz.U. z 2003 r. Nr 119, poz. 1117 z późn. zm.).

17 Por. U. Promińska, Znaki towarowe wspólne (kolektywne), „Studia Prawa Prywatnego” 2010, z. 1-2, s. 226.

18 Nie oznacza to jednak, że oznaczenia tego typu nie występowały - rejestrowane były jako znaki wspólne. Por. P. Kostański, [w:] P. Kostański (red.), Prawo własności przemysłowej, op. cit, s. 733.
} 
udzielone jedynie organizacji posiadającej osobowość prawną, która sama nie będzie znaku używać.

Przedstawiona definicja dotyka kilku kwestii, które wymagają dokładniejszego omówienia. Pierwszą z nich, istotną z punktu widzenia tematu artykułu, jest kwalifikacja podmiotowa uprawnionego do wspólnego znaku towarowego gwarancyjnego. Przytaczany już art. 137 ust. 1 PWPU wskazuje na trzy elementy: rejestracja tego rodzaju oznaczenia nastąpić może tylko na rzecz organizacji, przy czym musi ona posiadać osobowość prawną i dodatkowo nie może używać znaku zarejestrowanego na jej rzecz. ${ }^{19}$

Szczegółowa analiza powyższych przesłanek nie jest możliwa z racji ram niniejszych rozważań. Niemniej jednak zauważyć należy, że pierwsza z nich budzić może wątpliwości interpretacyjne, jako że termin „organizacja” nie mieści się w siatce pojęciowej prawa cywilnego. ${ }^{20}$ Większość autorów przyjmuje szerokie rozumienie, obejmując jego zakresem wszystkie osoby prawne: zarówno prawa prywatnego - takie jak spółki kapitałowe, stowarzyszenia czy fundacje, jak i prawa publicznego. ${ }^{21}$

Podkreślenia wymaga również, że organizacja uprawniona do wspólnego znaku towarowego gwarancyjnego sama nie może tego znaku używać. ${ }^{22}$ Dochodzi zatem, co jest cechą wyróżniającą tej instytucji prawnej, do „rozszczepienie prawa do znaku i prawa do jego używania". ${ }^{23}$ Rolą uprawnionego jest bowiem sprawowanie pieczy nad wspólnym znakiem towarowym gwarancyjnym. Oznacza to, że organizacja uznaje uprawnienie do używania oznaczenia przez zainteresowanych przedsiębiorców, a następnie kontroluje ich w zakresie wykorzystywania znaku. Jej jedynie służy także prawo dochodzenia roszczeń $\mathrm{z}$ tytułu naruszenia prawa ochronnego na wspólny znak towarowy gwarancyjny.

Dokładny zakres uprawnień organizacji, na rzecz której dokonywana jest rejestracja, powinien być jednym z elementów określonych w regulaminie wspólnego znaku towarowego gwarancyjnego. W myśl art. 138 ust. 4 PWPU regulamin taki musi wyznaczać co najmniej kryteria i tryb uznawania prawa przedsiębiorców do używania znaku, sposoby jego używania, zasady dokonywania przez organizację kontroli tych przedsiębiorców oraz sankcje za nieprzestrzeganie postanowień regulaminu. W dokumencie muszą zostać również zdefiniowane wspólne właściwości towarów lub usług, na które znak ma być nakładany.

\footnotetext{
19 Warto zauważyć, że wiele ustawodawstw dużo węziej zakreśla krąg podmiotów uprawnionych do rejestracji wspólnego znaku towarowego gwarancyjnego. Tak jest również w wypadku znaku wspólnotowego. Por. U. Promińska, Znaki towarowe..., op. cit., s. 224-225.

22 Warto zauważyć, że odmiennie uregulowana została sytuacja podmiotu uprawnionego do wspólnego znaku zwykłego. Jednakże w przypadku tej instytucji ustawodawca węziej określił krąg podmiotów uprawnionych do dokonania rejestracji. Por. P. Kostański, [w:] P. Kostański (red.), Prawo własności przemysłowej, op. cit., s. 721-732; U. Promińska, Znaki towarowe..., op. cit., s. 229-232. 
Ustawa nie określa ani charakteru prawnego regulaminu, ani nie rozstrzyga trybu, w jakim powinien być on przyjęty. ${ }^{24}$ Stanowi natomiast, że jego złożenie jest warunkiem sine qua non rejestracji wspólnego znaku towarowego gwarancyjnego. ${ }^{25}$ Za poważne przeoczenie ustawodawcy należy uznać brak wyraźnej regulacji dotyczącej obowiązku zgłaszania Urzędowi Patentowemu zmian regulaminu. Powszechnie przyjmuje się jednak, stosując celowościową wykładnię przepisów, istnienie takiego wymogu. ${ }^{26}$

Wskazać należy również, że regulamin znaku gwarancyjnego podlega udostępnieniu każdej osobie, która wskaże w tym swój interes prawny. ${ }^{27}$

Kwestią najważniejszą z punktu widzenia niniejszych rozważań jest to, iż wspólny znak towarowy gwarancyjny wskazuje na pewną cechę charakterystyczną, wspólną dla wszystkich towarów lub usług nim opatrzonych. ${ }^{28} \mathrm{O}$ tym, jaka będzie to cecha, decyduje w regulaminie uprawniony do znaku. Przepisy dotyczące wspólnego znaku towarowego gwarancyjnego w żaden sposób nie ingerują w zakres tego wyboru. Na względzie trzeba mieć jedynie ogólne przepisy dotyczące znaków towarowych, w szczególności w zakresie przeszkód rejestracji. Podkreślić jednak trzeba raz jeszcze, że muszą być one stosowane odpowiednio.

Odrębnej wzmianki wymaga przeszkoda rejestracji w postaci opisowego charakteru oznaczenia. Generalnie znak składający się ,wyłącznie z elementów mogących służyć w obrocie do wskazania w szczególności rodzaju towaru, jego pochodzenia, jakości, ilości, wartości, przeznaczenia, sposobu wytwarzania składu, funkcji lub przydatności" ${ }^{29}$ wyłączony jest bowiem od rejestracji w charakterze znaku towarowego, jako pozbawiony zdolności odróżniającej. Ratio legis tego rozwiązania jest potrzeba ochrony swobody prowadzenia działalności gospodarczej przez innych uczestników rynku, przed swoistą monopolizacją potrzebnych im oznaczeń. Oczywistym jest jednak, iż zastosowanie wprost tego przepisu do wspólnego znaku gwarancyjnego uniemożliwiałoby w zasadzie jego rejestrację. Opisowy charakter tego oznaczenia wpisany jest bowiem w jego naturę. Wydaje się, iż w przypadku wspólnego znaku gwarancyjnego odmowa rejestracji, w oparciu o przedmiotową przesłankę, winna mieć miejsce jedynie w sytuacjach wyjątkowych.

Za powyższą tezą przemawia również to, że w przypadku wspólnego znaku towarowego gwarancyjnego ustawodawca zapewnił dodatkową ochronę interesów pozostałych uczestników obrotu. Art. 137 ust. 2 PWPU stanowi, iż co do zasady uprawniony z prawa ochronnego na wspólny znak towarowy gwarancyjny nie może

\footnotetext{
$24 \quad$ Ibidem, s. 233-235.

$25 \quad$ Art. 138 ust. 3 PWPU.

26 P. Kostański, [w:] P. Kostański (red.), Prawo własności przemysłowej, op. cit., s. 729; U. Promińska, Znaki towarowe..., op. cit., s. 235. Art. 251 ust. 2 PWPU.

P. Kostański, [w:] P. Kostański (red.), Prawo własności przemysłowej, op. cit., s. 733.

Art. 129 ust. 2 pkt 2 PWPU. Por. M. Andrzejewski, [w:] P. Kostański (red.), Prawo własności przemysłowej, op. cit., s. 666-667.
} 
odmówić prawa używania tego znaku przedsiębiorcom, którzy spełnią kryteria określone w regulaminie znaku. Odmowa nastąpić może wyjątkowo, jedynie z ważnych powodów. ${ }^{30}$ Taka konstrukcja sprawia, że wspólny znak towarowy gwarancyjny pozostaje dostępny dla wszystkich zainteresowanych podmiotów, o ile tylko ich towary lub usługi posiadają określoną regulaminem charakterystyczną właściwość.

Kończąc tę część rozważań, trzeba jeszcze poruszyć kwestię funkcji wspólnego znaku towarowego gwarancyjnego. W pierwszej kolejności oznaczenie to pełni bowiem, odmiennie od ogólnego modelu znaku towarowego, na co wprost wskazuje zresztą jego nazwa, funkcję gwarancyjną. Informuje odbiorców, że oznaczone nim towary są w pewnym zakresie, wyznaczonym przez określoną $\mathrm{w}$ regulaminie wspólną właściwość, identyczne. W tym sensie wspólny znak gwarancyjny stanowi „sui generis «certyfikat jakości» produktu” 31 lub usługi. Dopiero w dalszej kolejności pełni funkcję oznaczania pochodzenia wskazując, że oznaczone nim towary lub usługi, przynajmniej w pewnym stopniu, znajdują się pod kontrolą tego samego podmiotu - organizacji uprawnionej do znaku. ${ }^{32}$

\section{Podsumowanie}

Przechodząc do próby udzielenia odpowiedzi na postawione na wstępie pytanie, należy po pierwsze zauważyć, że na gruncie obowiązującej PWPU, jednostki administracji publicznej będą mieściły się na ogół w kręgu podmiotów uprawnionych do uzyskania prawa ochronnego na wspólny znak towarowy gwarancyjny.

$\mathrm{Z}$ pewnością uprawnione do dokonania rejestracji są jednostki samorządu terytorialnego. Dopuścić także należy możliwość rejestracji wspólnego znaku towarowego gwarancyjnego przez Skarb Państwa. Uprawnienie takie zazwyczaj przysługiwać będzie również samorządowi gospodarczemu i zawodowemu, jak i fundacji. Za możliwe należy też uznać zarejestrowanie wspólnego znaku towarowego gwarancyjnego na rzecz spółek kapitałowych (np. spółek komunalnych), o ile one same nie będą takiego znaku używały.

Potwierdzenie, że administracja publiczna może uzyskać prawo ochronne na wspólny znak towarowy gwarancyjny, nie pozwala jednak jeszcze na udzielenie odpowiedzi na pytanie, czy i w jaki sposób może być on przez nią wykorzystany do realizacji idei zrównoważonego rozwoju.

Należy zauważyć, że koncepcja zrównoważonego rozwoju jest, jak każda idea, z natury swojej bardzo ogólna. Jak starano się pokazać powyżej, wypełniana jest treścią poprzez określone postulaty i wytyczne, wśród których wymienić można ochronę bioróżnorodności, zieloną gospodarkę, sprawiedliwy handel czy wykorzy-

\footnotetext{
30 Wprowadzenie takiego wentylu bezpieczeństwa w postaci generalnej klauzuli ważnych powodów uzasadnione jest potrzebą ochrony wspólnego znaku towarowego przed nadużyciami.

31 A. Szewc, G. Jyż, Prawo własności przemysłowej, Warszawa 2003, s. 101.

32 U. Promińska, Znaki towarowe..., op. cit., s. 227-229.
} 
stanie odnawialnych zasobów. Wszystkie one stanowią bardziej lub mniej szczegółowe cechy, którymi powinny charakteryzować się ludzkie działania, jeśli mają umożliwiać realizację idei zrównoważonego rozwoju.

Zdaniem autorów w tym miejscu widać właśnie rolę, jaką spełnić może wspólny znak towarowy gwarancyjny. Jako że jego główną funkcją jest wskazywanie na pewną właściwość, wspólną oznaczanym nim towarom, może on stanowić doskonałe narzędzie „wprowadzenia na rynek” tak pojmowanej idei zrównoważonego rozwoju (a precyzyjnie składających się na nią poszczególnych postulatów i wytycznych). Administracja publiczna, rejestrując tego rodzaju oznaczenia i nadając im poprzez działania marketingowe odpowiednią renomę i rozpoznawalność, jest w stanie promować zachowania zgodne z zasadą zrównoważonego rozwoju. Konsumenci sięgając po oznaczone takimi znakami towary otrzymają bowiem zapewnienie, że spełniają one określone standardy zgodne $\mathrm{z}$ tą zasadą, a jednocześnie będą mogli premiować swoimi wyborami przedsiębiorców wcielających ją w życie. Dla przedsiębiorców stanowić to powinno istotny bodziec ekonomiczny do wdrażania standardów pozwalających na realizację zasady zrównoważonego rozwoju w procesie produkcji towarów lub świadczenia usług.

Można sobie wyobrazić różne znaki towarowe tego typu: bardziej ogólne - wskazujące na przyczynianie się do zrównoważonego rozwoju określonego obszaru (np. „Zrównoważony Rozwój Mazowsza”), jak i odnoszące się do bardzo konkretnych cech towaru (np. „Sadzimy Las”).

By nie pozostawać jedynie w sferze hipotetycznych rozważań, warto przywołać oznaczenie „Jakość tradycyjna”. ${ }^{33}$ Zostało ono zarejestrowane jako wspólny znak towarowy gwarancyjny na rzecz Polskiej Izby Produktu Regionalnego i Lokalnego dla oznaczenia produktów pochodzących z upraw ekologicznych, która to właściwość także wpisuje się w ideę zrównoważonego rozwoju. Niestety, jest to jeden z nielicznych przykładów, a chyba jedyny o charakterze ogólnopolskim, wykorzystania w Polsce przez szeroko ujmowaną administrację publiczną wspólnego znaku towarowego gwarancyjnego do promocji idei zrównoważonego rozwoju.

Wskazując na celowość wykorzystywania przez administrację publiczną w jej działaniach wspólnych znaków towarowych gwarancyjnych, warto jeszcze na zakończenie przytoczyć stanowisko wyrażane w doktrynie, zgodnie z którym oznaczenia te, ze względu na swą funkcję, ,nabierają właściwego znaczenia właśnie wtedy, kiedy są rejestrowane przez podmioty prawa publicznego". ${ }^{34}$ 


\section{BIBLIOGRAFIA}

Andrzejewski M., [w:] P. Kostański (red.), Prawo własności przemysłowej. Komentarz, Warszawa 2010.

Bukowski Z., Zrównoważony rozwój w systemie prawa, Torun 2009.

Korzeniowski P., Zasady prawne ochrony środowiska, Łódź 2010.

Kostański P., [w:] P. Kostański (red.), Prawo własności przemysłowej. Komentarz, Warszawa 2010.

Papuziński A. (red.), Zrównoważony rozwój. Od utopii do praw człowieka, Bydgoszcz 2005.

Pearce D.W., Tuner R.K., Economics of Natural Resources and the Environmemt, New York 1990.

Promińska U., Znaki towarowe wspólne (kolektywne), „Studia Prawa Prywatnego” 2010, z. 1-2.

Szewc A., Jyż G., Prawo własności przemysłowej, Warszawa 2003.

Vanzetti A., Di Cataldo V., Manuale di diritto industriale, Milano 2012. 


\section{COLLECTIVE GUARANTEE TRADEMARK - AN INSTRUMENT OF PROMOTING SUSTAINABLE DEVELOPMENT?}

This article attempts to answer the question of whether the institution of collective guarantee trademark, coming from the industrial property law, can be used for public administration activities in aid of sustainable development. Firstly, the article outlines the concept of sustainable development and the legal framework of the institution of collective guarantee trademark. Secondly, it explains why, in the opinion of the authors, this kind of trademark is a useful instrument to promote the idea of sustainable development.

Keywords: collective guarantee trademark, sustainable development, public administration, industrial property law 